\title{
Penggunaan Accelerometer dan Magnetometer pada Sistem Real Time Tracking Indoor Position untuk Studi Kasus pada Gedung Teknik Informatika ITS
}

\author{
Dinar Winia Mahandhira, R. V. Hari Ginardi, dan Dini Adni Navastara \\ Jurusan Teknik Informatika, Fakultas Teknologi Informasi, Institut Teknologi Sepuluh Nopember \\ (ITS) \\ Jl. Arief Rahman Hakim, Surabaya 60111 Indonesia \\ e-mail: hari@its.ac.id,dini_navastara@if.its.ac.id,dinar.mahandhira@gmail.com
}

\begin{abstract}
Abstrak-Indoor Positioning System (IPS) menggunakan perangkat mobile seperti smartphone masih menjadi permasalahan yang menantang. Seperti GPS yang tidak bekerja secara akurat di dalam gedung, IPS juga memiliki kelemahan yaitu sangat bergantung pada infrastruktur gedung seperti sinyal WiFi yang terkadang tidak tersebar secara merata di seluruh bagian gedung, sehingga membuat sistem ini terkadang tidak dapat bekerja secara optimal dan real time di setiap bagian gedung. Untuk itulah dikembangkan IPS yang menggunakan sensor gerak seperti accelerometer dan magnetometer sebagai tambahan untuk melakukan update posisi secara real time dengan mendeteksi langkah dan arah hadap pengguna saat berjalan. Pertama, posisi awal pengguna harus ditentukan terlebih dahulu misalnya menggunakan sinyal WiFi yang diproses melalui klasifikasi. Setelah posisi pengguna telah ditentukan, sistem akan mendeteksi pergerakan pengguna secara real time menggunakan sensor gerak. Uji coba dilakukan menggunakan studi kasus gedung Teknik Informatika lantai tiga. Hasil yang diberikan pada saat pengujian memberikan performa yang cukup baik dengan rata-rata persentase akurasi untuk pendeteksian langkah dan estimasi arah hadap pengguna adalah sebesar $94,8 \%$ dan $94,48 \%$.
\end{abstract}

Kata Kunci-Indoor Localization, Location Based Service (LBS), Real Time Tracking Indoor Position, sensor Android

\section{PENDAHULUAN}

$\mathrm{P}$ ERKEMBANGAN teknologi Location Based Service (LBS) telah banyak mengalami perkembangan, seperti pengambilan gambar menggunakan teknologi geotagging, pelacakan keberadaan seseorang, dan navigasi menuju suatu tempat. LBS merupakan suatu layanan yang menyediakan informasi dengan memanfaatkan informasi geografis yang ada pada suatu perangkat bergerak dan memungkinkan untuk melakukan perhitungan yang berhubungan dengan lokasi dan jarak seseorang [1]. Hampir semua aktivitas LBS menggunakan teknologi Global Positioning System (GPS). Namun dibalik kegunaannya yang begitu besar, GPS masih memiliki kelemahan yaitu rendahnya akurasi saat digunakan di dalam gedung. Terlebih lagi GPS hanya memiliki konsep $2 D$ Localization dimana GPS tidak dapat membedakan lokasi ketinggian tempat atau gedung, serta tidak dapat membedakan informasi antar ruangan.
Solusi yang telah banyak dikembangkan untuk permasalahan ini adalah pemanfaatan infrastruktur gedung sebagai pengganti GPS, yaitu Radio Frequency (RF) seperti WiFi sebagai Access Point (AP). Teknologi ini biasanya disebut dengan Indoor Positioning System (IPS) yang didasari oleh magnetic, data sensor atau perangkat jaringan yang digunakan untuk menemukan suatu benda atau lokasi seseorang di dalam bangunan [2].

Namun muncul permasalahan baru saat infrastruktur gedung kurang memadai, misalnya sinyal WiFi pada suatu gedung tidak tersebar secara merata yang membuat sistem ini tidak dapat berjalan di beberapa titik yang tidak terjangkau sinyal WiFi dengan baik [3]. Untuk mengatasi permasalahan tersebut maka perlu digunakan pendekatan lain, misalnya penggunaan sensor untuk mengetahui pergerakan pengguna secara spesifik, apakah pengguna sedang melakukan pergerakan atau diam di tempat, serta mengetahui arah pergerakan itu sendiri.

Untuk mengatasi permasalahan tersebut maka perlu digunakan pendekatan lain misalnya penggunaan sensor untuk mengetahui pergerakan pengguna secara spesifik, apakah pengguna sedang melakukan pergerakan atau diam di tempat, serta mengetahui arah pergerakan itu sendiri. Hal tersebut juga dapat menjadi solusi untuk mengatasi permasalahan pendeteksian lokasi pengguna secara real time selain menggunakan klasifikasi WiFi.

\section{METODE PENELITIAN}

\section{A. Alur Kerja Sistem}

Sistem yang akan dibangun menggunakan konsep Indoor Localization. Konsep ini hampir sama dengan IPS, namun letak perbedaannya adalah IPS menentukan koordinat global sebuah lokasi seperti garis bujur dan garis lintang, sedangkan indoor localization menentukan koordinat relatif (contoh: Laboratorium KCV, IF-104, dll) [4].

Secara umum, alur kerja sistem yang digunakan untuk tracking indoor position ditampilkan seperti pada Gambar 1. Berdasarkan Gambar 1, perancangan alur arsitektur sistem ini adalah sebagai berikut.

1. Sistem menampilkan posisi awal pengguna pada peta 
2. Setelah menemukan posisi awal, sistem akan mendeteksi pergerakan pengguna menggunakan sensor.

3. Sensor akan terus mengumpulkan data selama aplikasi masih berjalan.

4. Jika terjadi perubahan nilai pada data sensor, maka aplikasi akan melakukan update terhadap posisi pengguna saat itu juga.



Gambar 1. Alur Kerja Sistem

\section{B. Pendeteksian Arah dan Pergerakan Pengguna}

Pendeteksi pergerakan adalah sebuah teknik yang digunakan untuk mendeteksi dan mengetahui apakah suatu pengguna sedang bergerak atau tidak. Teknik ini digunakan dengan cara menghitung nilai signifikansi dari nilai perubahan sensor. Dalam hal ini, pendeteksian arah dan pergerakan pengguna didapatkan dari pembacaan sensor accelerometer dan magnetometer. Magnetometer adalah suatu sistem atau perangkat yang bekerja atas dasar pendeteksian gaya magnet bumi. Biasanya magnetometer digunakan untuk menentukan arah mata angin. Pada perangkat mobile, magnetometer memiliki output berupa besar medan magnet bumi yang diukur dalam tiga sumbu orientasi yaitu $\mathrm{x}, \mathrm{y}$, dan z. Dalam hal positioning, sensor ini digunakan untuk menentukan arah ketika pengguna sedang menuju suatu tempat. Untuk menghindari kesalahan pengukuran pada keadaan sensor miring, biasanya penggunaan sensor magnetometer akan digabungkan dengan output dari accelerometer [3].

Karena sensor magnetometer digunakan untuk menentukan arah hadap pengguna secara horizontal, maka yang perlu diperhatikan hanyalah perubahan nilai pada orientasi sumbu $\mathrm{x}$ saja. Untuk alur kerja dari sensor magnetometer dapat dilihat pada Gambar 2.

Sedangkan accelerometer adalah sebuah sensor yang digunakan untuk mengukur percepatan suatu objek, baik statis maupun dinamis. Alat ini bekerja berdasarkan hukum fisika. Secara statis, accelerometer melakukan pengukuran terhadap gravitasi bumi. Sedangkan secara dinamis, accelerometer melakukan pengukuran terhadap percepatan atau perpindahan pada objek yang bergerak [4]. Pada smartphone, sensor accelerometer terdiri dari tiga sumbu yaitu $\mathrm{x}, \mathrm{y}$, dan $\mathrm{z}$ dengan orientasi yang berbeda-beda untuk setiap sumbu. Dalam penentuan posisi menggunakan smartphone, data yang dihasilkan accelerometer biasanya digunakan untuk step detection yang kemudian diolah untuk memperkirakan pergerakan dari pengguna. Karena nilai yang dihasilkan dari sensor ini masih dipengaruhi oleh gaya gravitasi, maka perlu dilakukan preprocessing terhadap nilai keluaran dari accelerometer untuk menghilangkan gaya gravitasi, misalnya dengan metode low-pass filter.

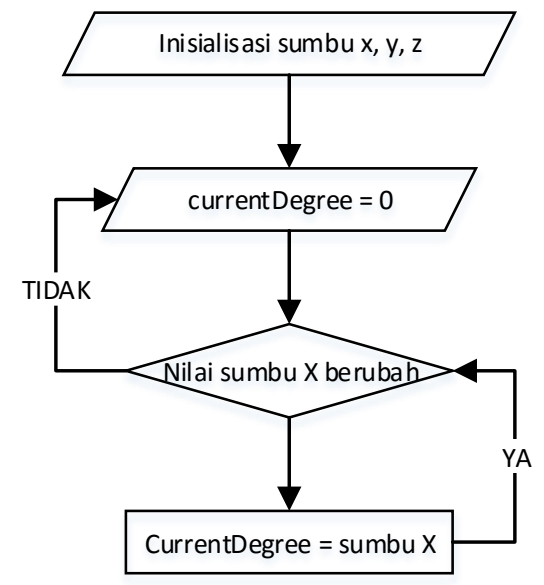

Gambar 2. Diagram Alir Kerja Magnetometer

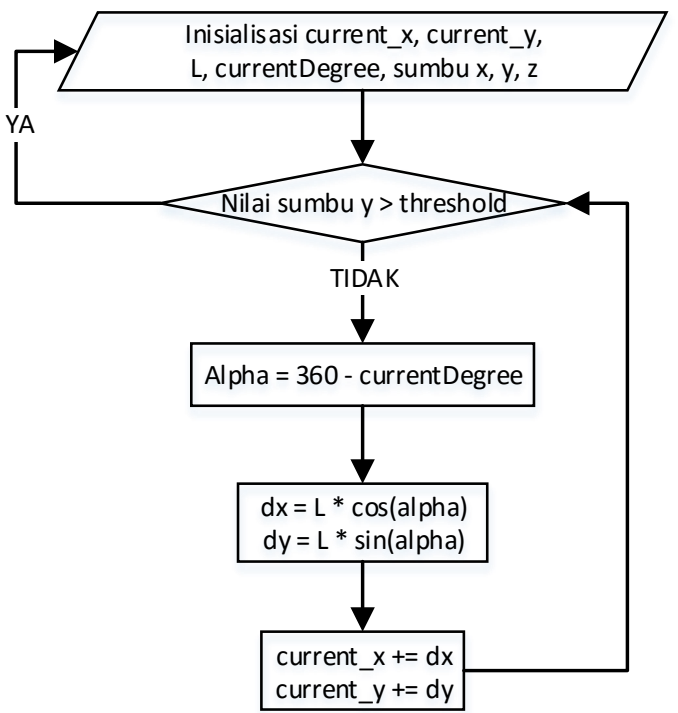

Gambar 3. Diagram Alir Kerja Accelerometer

Penggunaan sensor accelerometer pada sistem ini adalah untuk mengetahui apakah pengguna sedang bergerak maju atau tidak. Perlu diperhatikan bahwa sistem ini selalu menganggap segala pergerakan adalah maju ke depan. Oleh karena itu, yang perlu diperhatikan cukup nilai dari sumbu y apakah melebihi threshold yang ditentukan atau tidak. Jika nilai sumbu y tidak melebihi threshold, maka pengguna dianggap sedang berjalan. Kemudian marker yang menandakan posisi pengguna saat itu akan digeser dengan jarak tertentu kea rah yang telah ditentukan sensor magnetometer. Alur kerja dari accelerometer dapat dilihat pada Gambar 3.

Saat pengguna berjalan menggunakan aplikasi, posisi 
smartphone harus berada dalam kondisi steady hand, yaitu smartphone selalu berada dalam posisi mendatar. Hal ini dikarenakan accelerometer akan memprediksi pergerakan maju pengguna, sehingga jika posisi smartphone tidak selalu mendatar, akan mempengaruhi nilai sumbu y yang berubah secara tidak normal. Perubahan nilai sumbu y yang tidak normal ini nantinya juga akan mempengaruhi step detection pada sistem, dimana jika guncangan atau perubahan nilai pada sumbu y melebihi threshold tidak akan dianggap sebagai sebuah langkah. Hal ini mengakibatkan sistem tidak akan menunjukkan performa yang bagus.

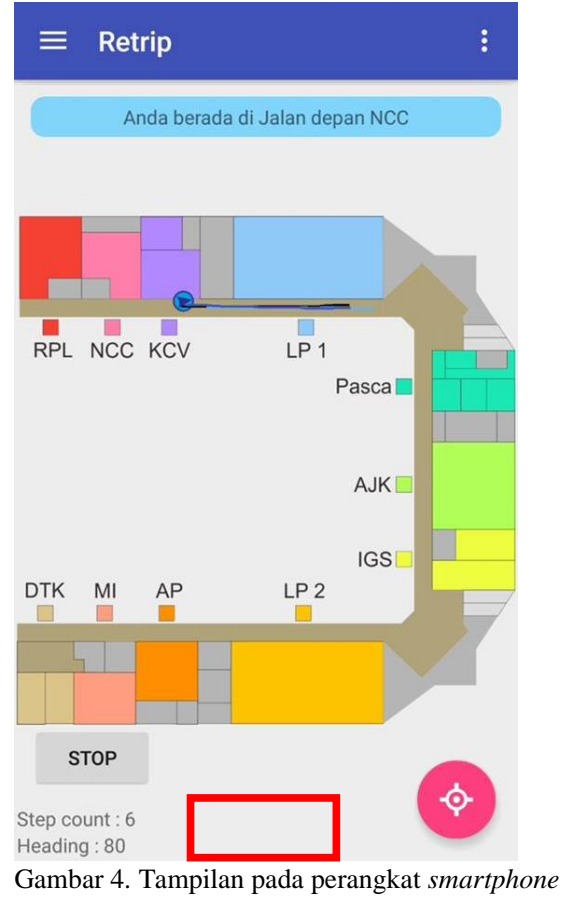

\section{UJI COBA DAN EVALUASI}

Aplikasi yang dibangun sebagai implementasi sistem merupakan aplikasi Android yang berjalan dengan sistem operasi Android minimal 5.0. Perangkat smartphone yang digunakan sebagai perangkat pengembangan dan pengujian harus memiliki sensor accelerometer dan magnetometer. Pada Gambar 4 dijelaskan implementasi dari sistem yang digunakan untuk uji coba.

Perhitungan langkah (step count) dan estimasi arah hadap (heading) saat uji coba ditampilkan pada layar bagian bawah. Setiap ada perubahan langkah, jumlah step count akan terus bertambah sedangkan setiap perubahan arah akan ditampilkan pada heading dalam satuan derajat. Uji coba yang dilakukan pada gedung Teknik Informatika ITS lantai tiga. Pengujian akurasi sistem dilakukan dengan menentukan empat rute yang masing-masing memiliki titik awal dan akhir. Pada setiap rute, dilakukan lima kali percobaan dan pengguna berjalan melalui rute tersebut menggunakan aplikasi yang telah dibuat. Untuk pola setiap rute yang dijadikan uji coba dapat dilihat pada Gambar 5.

Setiap kali percobaan akan dicatat akurasi pendeteksian langkah pengguna serta estimasi arah hadap. Hasil pengujian yang dilakukan akan dijelaskan lebih rinci sebagai berikut.

1. Pengujian akurasi deteksi langkah pengguna

Nilai akurasi pendeteksian langkah pengguna dihitung dengan membandingkan jumlah langkah yang terdeteksi pada aplikasi dengan jumlah langkah sebenarnya. Secara keseluruhan rata-rata akurasi pendeteksian langkah pengguna pada sistem ini sudah cukup baik yaitu sebesar $94,8 \%$ seperti ditunjukkan pada Tabel 1.

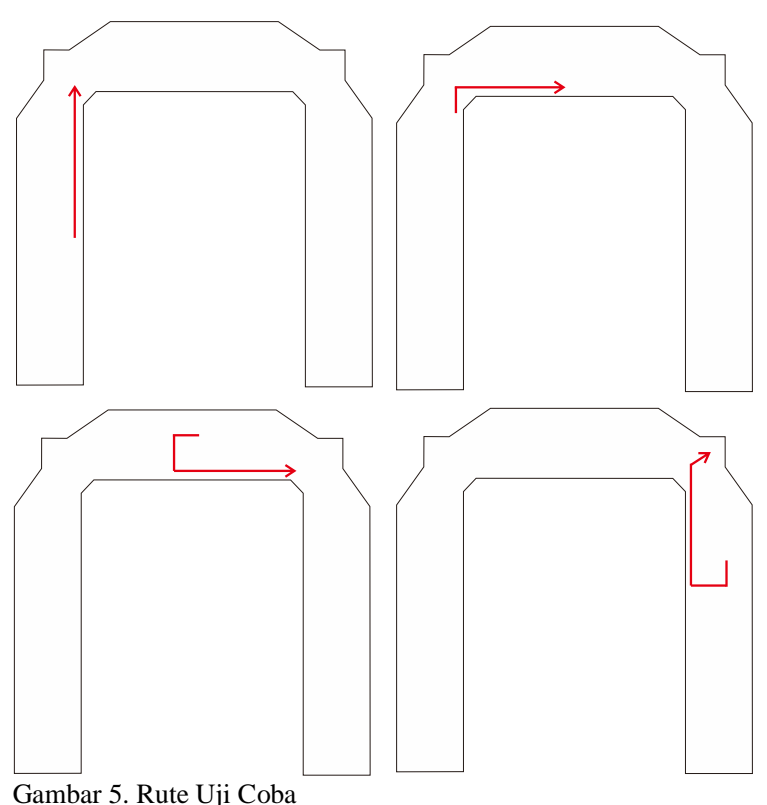

Tabel 1.

\begin{tabular}{cc} 
Hasil Pengujian Akurasi Step Detection \\
\hline \hline Rute & Akurasi \\
\hline Rute 1 & $97,8 \%$ \\
Rute 2 & $96,2 \%$ \\
Rute 3 & $92,7 \%$ \\
Rute 4 & $92,3 \%$ \\
Rata-rata & $\mathbf{9 4 , 8 \%}$ \\
\hline \hline
\end{tabular}

2. Pengujian akurasi estimasi arah hadap

Pengujian dilakukan dengan membandingkan hasil aplikasi dengan ground truth, yaitu aplikasi kompas lain yang telah ada sebelumnya.

Tabel 2.

Hasil Pengujian Akurasi Estimasi Arah Hadap

\begin{tabular}{cc}
\hline Rute & Akurasi \\
\hline Rute 1 & $97,8 \%$ \\
Rute 2 & $96,2 \%$ \\
Rute 3 & $92,7 \%$ \\
Rute 4 & $92,3 \%$ \\
Rata-rata & $\mathbf{9 4 , 4 8 \%}$ \\
\hline \hline
\end{tabular}

Dari seluruh percobaan yang dilakukan, rata-rata akurasi estimasi arah hadap pengguna pada sistem ini cukup baik yaitu sebesar 94,48\% dengan rincian seperti pada Tabel 2.

\section{KESIMPULAN}

Pada paper ini telah dijelaskan mengenai metode pengembangan IPS menggunakan sensor motion yaitu 
accelerometer dan magnetometer sebagai solusi real time tracking indoor position terutama saat penentuan posisi pengguna tidak bisa ditentukan dengan cepat karena infrastruktur gedung yang kurang memadai seperti sinyal WiFi pada gedung yang tidak tersebar secara merata. Pengujian pada sistem menghasilkan rata-rata persentase akurasi untuk pendeteksian langkah dan arah hadap pengguna adalah sebesar $94,8 \%$ dan $94,48 \%$.

\section{DAFTAR PUSTAKA}

[1] S. Kumar, M. A. Qadeer and A. Gupta, "Location Based Services using Android (LBSOID)," 2009.

[2] K. Curran, E. Furey, T. Lunney, J. Santos, D. Woods and A. Caughey, "An Evaluation of Indoor Location Determination Technologies," Journal of Location Based Services, vol. 5, pp. 61-78, 2011.

[3] W. Waqar, Y. Chen and A. Vardy, "Smartphone positioning in sparse WiFi environments," Computer Communications, pp. 1-9, 2015.

[4] G. Millette, Android Sensor Programming, Indianapolis: John Wiley \& Sons Inc., 2012. 